\title{
The optimization of low-magnesium zinc concentrate production process
}

\author{
Andrzej Jarosiński, Katarzyna Fela \\ Cracow University of Technology, Institute of Inorganic Chemistry and Technology, ul. Warszawska 24, 31-155 Kraków, \\ Poland, e-mail: kf@chemia.pk.edu.pl
}

\begin{abstract}
In this paper the result of the study on chemical leaching of zinc concentrate with $\mathrm{H}_{2} \mathrm{SO}_{4}$ solution was presented. The object of this work was to assess the effect of some parameters such as acid concentration, the leaching agent amount/stoichiometry amount or excess of acid were applied/, reaction time and temperature on the process. The investigation was performed as a active experiment according to Hartley's plan. The process optimisation procedure was based on the fuzzy logic system. Mainly, the parameters such as magnesium leaching efficiency and zinc losses were taken into account. It was stated that the highest magnesium leaching efficiency of $77.8 \%$ with low $\mathrm{Zn}$-losses was reached when $\mathrm{H}_{2} \mathrm{SO}_{4}$ solution concentration was $2.5 \%$ for $20 \%$-excess of acid, at temperature $25^{\circ} \mathrm{C}$ and process time of 1 hour.
\end{abstract}

Keywords: Zn-concentrate, magnesium removal, chemical treatment, acid leaching.

\section{INTRODUCTION}

The principal source from which zinc is produced commercially is the mineral sphalerite $(\mathrm{ZnS})$, also known as blende. It accounts for $90 \%$ of the present zinc production. Deposits of $\mathrm{Zn}$-bearing raw material occur in about 50 countries, and the world industrial zinc reserves are estimated at $140 \mathrm{mln}$ tonnes. In Poland Zn-ore, mainly sphalerite beds are located in Silesia-Cracow region. Here the ore occurs as finely disseminated bands of sphalerite and galena $(\mathrm{PbS})$ with some dolomite, in the host rock $^{1-3}$.

These sulphide ores are enriched mainly by the way of flotation. In the world as well as in domestic conditions selective and collective concentrates are the final products of the above processing. In the selective flotation of zinclead ores, blende concentrate is obtained after the floating of galena. The zinc concentrates contain a relatively high content of magnesium, even up to about 2,5\% $\mathrm{MgO}$. The content of magnesium is also higher, especially for a correct hydrometallurgical process course and should be reduced to a level of $0.5-1.0 \%$. The increment of magnesium concentration in the electrolyte is one of the factors liable for decreasing of cathode zinc quality. Moreover, the high concentration of magnesium influences unprofitably the technical and economic indexes. Therefore, many investigations have been performed for zinc ore with the view to preparing the concentrate of high quality parameters ${ }^{\mathbf{4}}{ }^{10}$. Reduction of magnesium content in the concentrate can be realized by leaching with acids ${ }^{10}$. Magnesium is also removed from the electrolyte used for the electrodeposition of zinc $^{11}$. The purpose of this process is to obtain the material of desired properties, low magnesium concentration. The use of sulphuric acid solutions in the pre-leaching and purification of blende concentrate is connected with the low cost of this acid in relation to other useable acids. Moreover, in the case of obtaining zinc, the electrolysis from the sulphate solution is preferred for the sake of its simplicity and the high quality of the final product as well as the resource of professional experience collected upon hydrometallurgical processes and the electrodeposition of zinc.

This paper deals with the attempts to develop a method of magnesium elimination from zinc concentrate deriving from the beneficiation of domestic sulphide zinc and lead ores. The authors tried to substantiate the existing relationships as well as to determine the optimum conditions for the procedure suggested.

\section{EXPERIMENTAL}

The objective of the study was to determine the conditions of zinc concentrate demagnesation process. The laboratory research was carried out as an active experiment according to Hartley's plan (PS/DS-P:Ha $\left.{ }_{4}\right)^{\mathbf{1 2}}$. The basic stages of the investigation, zinc concentrate acid leaching, suspension filtration, solution (leachate) and solids analyses were realized.

The following raw material was applied: domestic Znconcentrate derived from Trzebionka Mine Plant containing [\%]: $55.63-\mathrm{Zn}, 1.30-\mathrm{Mg}, 2.48-\mathrm{Ca}, 1.35-\mathrm{Fe}(\mathrm{II})$, and $4.66-\mathrm{Pb}$. The main crystalline phases identified in the material are sphalerite $(\mathrm{ZnS})$, galene $(\mathrm{PbS})$, ancerite $\left(\mathrm{Ca}\left(\mathrm{Mg}_{0.67} \mathrm{Fe}_{0.33}\right)\left(\mathrm{CO}_{3}\right)_{2}\right)$, magnesite $\left(\mathrm{MgCO}_{3}\right)$, and peryclase $(\mathrm{MgO})$. For leaching of the concentrate sulphuric acid solution of the concentration 2.5, 5.0 and 7.5\% was used. The quantity of the leaching agent was determined on the base of dolomite decomposition reaction. Experiments with the stoichiometric amount of acid and using its excess of 10 and $20 \%$ were provided.

The laboratory tests were realized as follows: $20 \mathrm{~g}$ of raw $\mathrm{Zn}$-concentrate were leached for 20,40 or 60 minutes at $25,37.5$ or $50^{\circ} \mathrm{C}$ in a thermostated flask equipped with a mechanical stirrer. The conditions of these experiments are presented in Table 1. Next, the obtained suspension was filtrated. The leachates and solids were analyzed to estimate the basic component contents. For the mineralization of solid samples a mixture of hydrochloric and nitric acids of 1:3 volume ratio was used.

ICP AES spectroscopy /spectrophotometer PerkinElmer "PLASMA 40"/ was used for $\mathrm{Mg}^{2+}, \mathrm{Zn}^{2+}, \mathrm{Ca}^{2+}$, $\mathrm{Pb}^{2+}$ and $\mathrm{Fe}^{2+}$ ions concentration in solution evaluation. $\mathrm{X}$-ray powder diffraction /a Philips X'Pert Diffractometer with $\mathrm{CuK}_{\alpha}$ radiation/ was used to analyze phase compositions for solids.

On the basis of the investigation results, the basic parameters of the process, magnesium leaching efficiency and zinc losses were calculated. 
Table 1. The process conditions of the $\mathrm{Zn}$-concentrate leaching with $\mathrm{H}_{2} \mathrm{SO}_{4}$ solutions

\begin{tabular}{|c|c|c|c|c|}
\hline Sample & $\begin{array}{c}\text { Time } \\
\text { [min] }\end{array}$ & $\begin{array}{c}\mathrm{H}_{2} \mathrm{SO}_{4} \\
\text { concentrat } \\
\text { ion }[\%]\end{array}$ & $\begin{array}{c}\text { Temperatu } \\
\text { re }\left[{ }^{\circ} \mathrm{C}\right]\end{array}$ & $\begin{array}{c}\text { Acid } \\
\text { excess }\end{array}$ \\
\hline $\mathrm{A} 1$ & 60 & 2.5 & 25.0 & 1.0 \\
\hline $\mathrm{A} 2$ & 20 & 7.5 & 25.0 & 1.0 \\
\hline $\mathrm{A} 3$ & 20 & 2.5 & 50.0 & 1.0 \\
\hline $\mathrm{A} 4$ & 60 & 7.5 & 50.0 & 1.0 \\
\hline $\mathrm{A} 5$ & 60 & 2.5 & 25.0 & 1.2 \\
\hline $\mathrm{A} 6$ & 20 & 7.5 & 25.0 & 1.2 \\
\hline $\mathrm{A} 7$ & 20 & 2.5 & 50.0 & 1.2 \\
\hline $\mathrm{A} 8$ & 60 & 7.5 & 50.0 & 1.2 \\
\hline $\mathrm{A} 9$ & 20 & 5.0 & 37.5 & 1.1 \\
\hline $\mathrm{A} 10$ & 60 & 5.0 & 37.5 & 1.1 \\
\hline $\mathrm{A} 11$ & 40 & 2.5 & 37.5 & 1.1 \\
\hline $\mathrm{A} 12$ & 40 & 7.5 & 37.5 & 1.1 \\
\hline $\mathrm{A} 13$ & 40 & 5.0 & 25.0 & 1.1 \\
\hline $\mathrm{A} 14$ & 40 & 5.0 & 50.0 & 1.1 \\
\hline $\mathrm{A} 15$ & 40 & 5.0 & 37.5 & 1.0 \\
\hline $\mathrm{A} 16$ & 40 & 5.0 & 37.5 & 1.2 \\
\hline $\mathrm{A} 17$ & 40 & 5.0 & 37.5 & 1.1 \\
\hline
\end{tabular}

The process optimisation procedure was based on the fuzzy logic system ${ }^{\mathbf{1 3}} \mathbf{- 1 5}$. The estimation of the process parameters was made by the matrix method in which Leopold's causal-effect matrix was used. This matrix is designed as a grid of rows and columns where the conducted laboratory attempts (sample numbers) are provided in rows, and the leaching process parameters in columns. According to the chosen criteria, the values of the characteristic process parameters were located in a common cell. The accepted values are denoted by "+", not accepted by "-" and admissible by "+/-". The tests, for which one or more parameters values were determined as not acceptable, were discarded. The test, for which all or the majority of values of all parameters were determined as acceptable, was considered an optimal condition of the leaching process.

\section{RESULTS}

These investigations determined the process condition effect on the efficiency of magnesium removal from zinc concentrate and the efficiencies of other metals /concentrate components/ leaching. They were calculated with the following formula:

$\mathrm{w}=\left(\mathrm{V} \cdot \mathrm{c}_{1} / \mathrm{m} \cdot \mathrm{c}_{0} / 100\right) \cdot 100 \%$

where: $\mathrm{w}-$ metal leaching efficiency [\%], $\mathrm{c}_{1}$ - the metal concentration in the solution (leachate) $\left[\mathrm{g} / \mathrm{dm}^{3}\right], \mathrm{c}_{0}-$ the initial metal concentration in the raw concentrate [\%], $\mathrm{V}$ - the volume of the leachate $\left[\mathrm{dm}^{3}\right], \mathrm{m}$ - the initial mass of the concentrate $[\mathrm{g}]$.

Magnesium removal efficiency, in the majority of cases, ranged from 30 to $75 \%$. Only for four experiments it does not exceed $20 \%$. The highest $\mathrm{Mg}$ leaching efficiencies, above $68 \%$ were achieved for the tests denoted by A1, A3, A5, A7 and A11 symbols. The efficiencies of Mg leaching, obtained in all experimental tests are presented in Fig.1. Magnesium contents in the leached material dried at room temperature range from 0.3 to $1.2 \%$.

The obtained experiment results cannot be directly used to determine the optimum leaching conditions and just because the simplified Leopold's matrix was used for the process optimisation. The choice was made according to the criteria presented in Table 2 . The calculated process parameters and optimisation results are given in Table 3.

The $\mathrm{Zn}$-losses, at $\mathrm{Mg}$ removal from zinc concentrate are also an important parameter of the process. The results of leachates analysis show that zinc losses do not exceed $1 \%$. Its maximum value is $0.8 \%$, but in the majority of causes it is about $0.2 \%$. The high Zn-losses are observed in experiments when high temperature and/or long times were applied.

The presence of soluble metallic impurities in the electrolyte is harmful for zinc deposition, therefore in the experiments the leaching degrees of some main elements, $\mathrm{Fe}, \mathrm{Pb}$ and $\mathrm{Ca}$ were controlled. It was stated that lead extraction is very low, ranged from $0.004-0.022 \%$. It is a consequence of lead sulphate resistance to diluted sul-

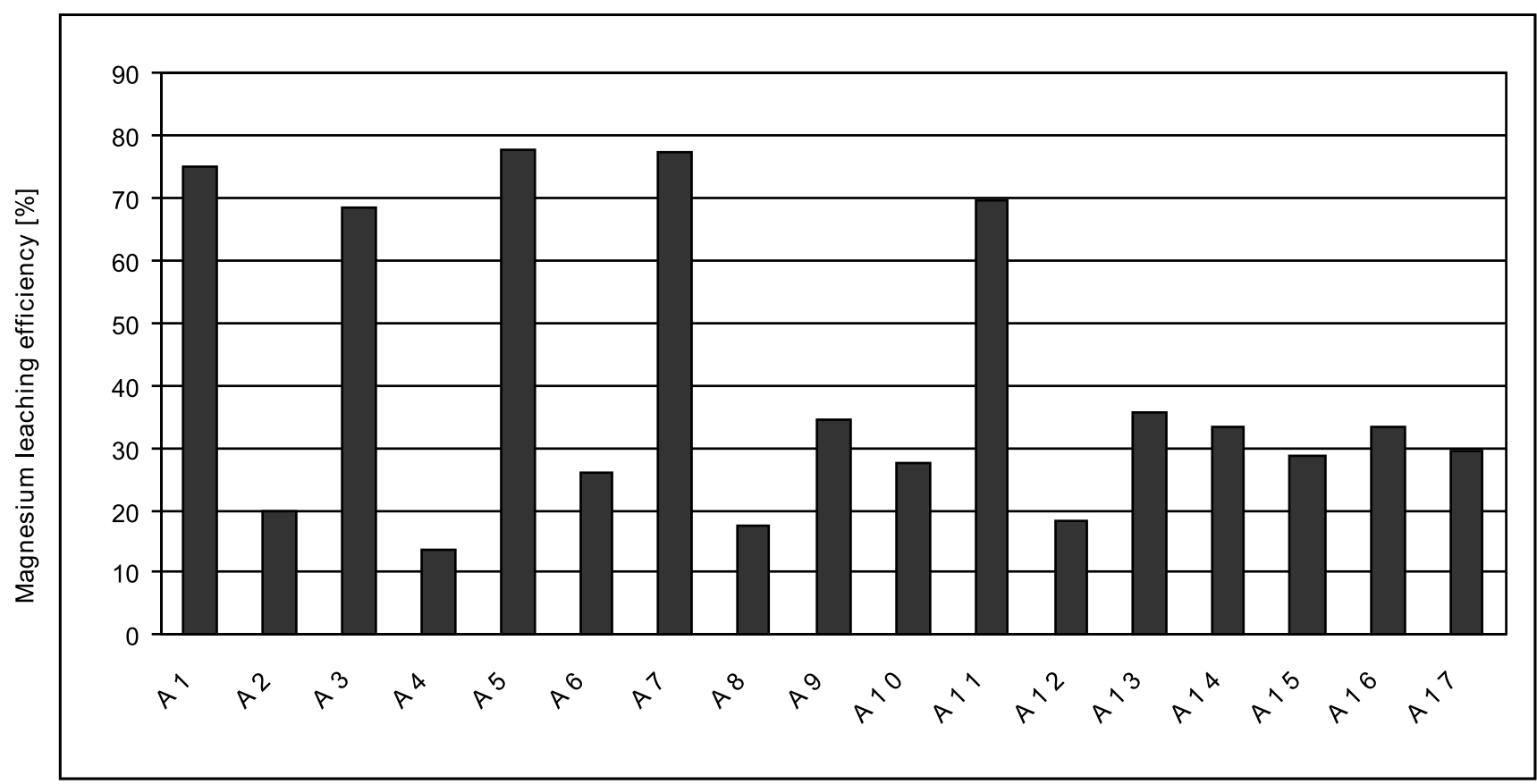

Figure 1. Magnesium leaching efficiency obtained in all the experimental tests 
Table 2. The estimation criteria of the parameters of the Zn-concentrate leaching with $\mathrm{H} 2 \mathrm{SO} 4$ solutions

\begin{tabular}{|c|c|c|c|c|c|}
\hline \multirow{2}{*}{ Estimation criteria } & \multicolumn{4}{|c|}{ Component leaching efficiency [\%] } & $\begin{array}{c}\text { Mg content in leached } \\
\text { material [\%] }\end{array}$ \\
\cline { 2 - 5 } & $\mathrm{Mg}$ & $\mathrm{Zn}$ & $\mathrm{Fe}$ & $>0.01$ & $\leq 0.3$ \\
\hline $\begin{array}{c}\text { accepted } \\
\text { +" }\end{array}$ & $>68$ & $<0.3$ & $>7.0$ & $0.005-0.010$ & $0.3-0.7$ \\
\hline $\begin{array}{c}\text { admissible } \\
\text { "/-" }\end{array}$ & $40-68$ & $0.3-0.8$ & $4.0-7.0$ & $<0.005$ & $\geq 0.7$ \\
\hline $\begin{array}{c}\text { not accepted } \\
\text {," }\end{array}$ & $<40$ & $>0.8$ & $<4.0$ & $<$ \\
\hline
\end{tabular}

Table 3. The process parameters of the $\mathrm{Zn}$-concentrate leaching with $\mathrm{H}_{2} \mathrm{SO}_{4}$ solutions

\begin{tabular}{|c|c|c|c|c|c|c|c|c|c|c|c|}
\hline \multirow{3}{*}{$\begin{array}{c}\text { Sample } \\
\text { A1 }\end{array}$} & \multicolumn{9}{|c|}{ Component leaching efficiency [\%] } & \multirow{2}{*}{\multicolumn{2}{|c|}{$\begin{array}{c}\text { Mg content } \\
\text { in leached material [\%] }\end{array}$}} \\
\hline & \multicolumn{2}{|c|}{$\mathrm{Mg}$} & \multicolumn{2}{|c|}{$\mathrm{Zn}$} & \multicolumn{2}{|c|}{$\mathrm{Fe}$} & \multicolumn{2}{|c|}{$\mathrm{Pb}$} & \multirow{2}{*}{$\begin{array}{c}\mathrm{Ca} \\
\text { n.o. }\end{array}$} & & \\
\hline & 75.06 & + & 0.70 & $+/-$ & 15.3 & + & 0.018 & + & & 0.3 & + \\
\hline A2 & 19.94 & - & 0.20 & + & 2.2 & - & 0.004 & - & 7.92 & 1.1 & - \\
\hline A3 & 68.66 & + & 0.76 & $+/-$ & 13.8 & + & 0.016 & + & 1.92 & 0.4 & $+/-$ \\
\hline $\mathrm{A} 4$ & 13.58 & - & 0.10 & - & n.o. & & 0.002 & - & 6.57 & 1.2 & - \\
\hline A5 & 77.81 & + & 0.78 & $+/-$ & 17.3 & + & 0.023 & + & 1.05 & 0.3 & + \\
\hline A6 & 25.89 & - & 0.23 & + & 3.5 & - & 0.006 & $+/-$ & 10.04 & 1.0 & - \\
\hline A7 & 77.24 & + & 0.89 & - & 17.1 & + & 0.022 & + & 2.71 & 0.3 & + \\
\hline A8 & 17.40 & - & 0.13 & + & n.o. & & 0.003 & - & 9.00 & 1.1 & - \\
\hline A9 & 34.43 & - & 0.27 & + & 4.5 & $+/-$ & 0.008 & $+/-$ & 1.33 & 0.9 & - \\
\hline A10 & 27.58 & - & 0.21 & + & 2.4 & - & 0.006 & $+/-$ & 3.00 & 1.0 & - \\
\hline A11 & 69.69 & + & 0.76 & $+/-$ & 15.6 & + & 0.019 & + & 2.71 & 0.4 & $+/-$ \\
\hline A12 & 18.10 & - & 0.16 & + & 1.1 & - & 0.004 & - & 7.74 & 1.1 & - \\
\hline A13 & 35.85 & - & 0.27 & + & 4.8 & $+/-$ & 0.008 & $+/-$ & 1.60 & 0.9 & - \\
\hline A14 & 33.27 & - & 0.24 & + & 3.0 & - & 0.007 & $+/-$ & 3.46 & 0.9 & - \\
\hline A15 & 28.86 & - & 0.22 & + & 3.0 & - & 0.006 & $+/-$ & 2.91 & 1.0 & - \\
\hline A16 & 33.47 & - & 0.23 & + & 4.3 & $+/-$ & 0.008 & $+/-$ & 2.55 & 0.9 & - \\
\hline A17 & 29.72 & - & 0.22 & + & 3.5 & - & 0.007 & $+/-$ & 2.96 & 1.0 & - \\
\hline
\end{tabular}

n.o. - not analyzed

phuric acid solutions agency. However, it was seen that increase of solubility of $\mathrm{PbS}$, concentration of $\mathrm{Pb}^{2+}$ ion in leachate results from the higher concentration of $\mathrm{H}_{2} \mathrm{SO}_{4}$. The efficiency of calcium leaching is low. The maximum calcium leaching degree obtained in the experimental study is $10 \%$. One of the products of dolomite decomposition reaction is the low-soluble calcium sulphate. Therefore, $\mathrm{Ca}$ compounds remain in the solid phase. Iron leaching efficiency ranged from $1.11 \%$ to $17.3 \%$. The high values of this parameter are obtained for the low-acid solution concentration, $2.5 \%$.

On the basis of the above selection results it can be seen that the satisfactory values of the process parameters were obtained for the samples denoted by A1, A3, A5 and A11. The results suggest that $2.5 \% \mathrm{H}_{2} \mathrm{SO}_{4}$ is the optimal concentration. The temperature increasing from 25 to $50^{\circ} \mathrm{C}$ allows to shorten the leaching time from 60 to 20 minutes and to apply stoichiometry amount of the sulphuric acid /not exceed/.

The final leach residues were examined by X-ray diffraction. The diffraction patterns of some selected samples are shown in Fig. 2. It was stated that the main components of the analyzed materials are sphalerite. In the concentrate the presence of galena has also been noticed. Besides in samples A1 and A5 bassanite $\left(\mathrm{CaSO}_{4} \cdot 0.5 \mathrm{H}_{2} \mathrm{O}\right)$ was identified. It is the consequence of calcium sulphate(VI) crystallization in the reaction system. In none of the leached samples magnesium compounds presence was found. Since during the sulphuric(VI) acid leaching in the system calcium sulphate(VI) crystallizes, the cleaning flotation of the material is demanded.

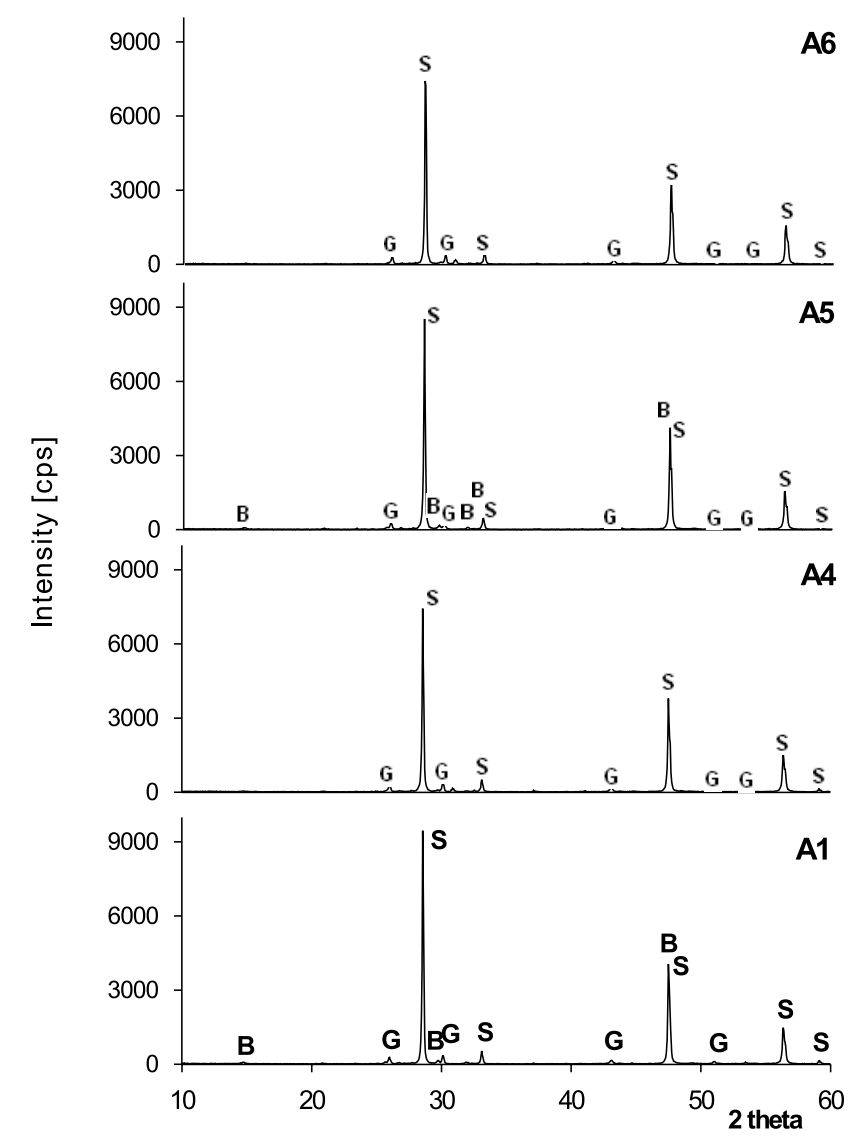

Figure 2. X-ray powder diffraction patterns of some leached Zn-concentrate samples (B - bassanite $\left(\mathrm{CaSO}_{4} \cdot 0.5 \mathrm{H}_{2} \mathrm{O}\right), \mathrm{G}$ - galene $(\mathrm{PbS}), \mathrm{S}-$ sphalerite $(\mathrm{ZnS}))$ 
It is also the reason that $\mathrm{Ca}$ leaching efficiency was not taken into account in the process assess procedure.

On the base of the experimental results applying MathCad13 program function of the research object was determined. The function expresses the dependence between the independent variable, arguments of the function: reaction time $x_{1}$, acid concentration $x_{2}$, process temperature $x_{3}$ and the amount of acid $x_{4}$ and magnesium leaching efficiency $z$. The determined form of the equation of a function is as follows:

$\mathrm{z}=0.561 \mathrm{x}_{1}-25.559 \mathrm{x}_{2}-1.568 \mathrm{x}_{3}-254.297 \mathrm{x}_{4}-$ $3.428 \cdot 10^{-3} \mathrm{x}_{1}{ }^{2}+1.814 \mathrm{x}_{2}{ }^{2}+0.013 \mathrm{x}_{3}{ }^{2}+129.378 \mathrm{x}_{4}^{2}-$ $0.029 \mathrm{x}_{1} \mathrm{x}_{2}-8.617 \mathrm{x}_{1} \mathrm{x}_{3}-0.017 \mathrm{x}_{1} \mathrm{x}_{4}+0.089 \mathrm{x}_{2} \mathrm{x}_{3}-4.623 \mathrm{x}_{2} \mathrm{x}_{4}$ $+0.367 \mathrm{x}_{3} \mathrm{x}_{4}+275.934$

The function reaches its maximum at 37 minutes of the reaction time, $2.5 \%$ acid concentration, temperature of $25^{\circ} \mathrm{C}$ and leaching agent excess of 1.2. Putting these parameters values into the equation we found the maximum value of magnesium leaching efficiency that equals $80.81 \%$.

\section{CONCLUSION}

The studies of the zinc concentrate leaching process with sulphuric acid solutions of low concentrations confirmed the usefulness of this method for magnesium removal. The process examination permits to select the optimum of its conditions. The highest magnesium leaching efficiency of $77.81 \%$ was reached for $\mathrm{H}_{2} \mathrm{SO}_{4}$ solution concentration of $2.5 \%$ for $20 \%$ excess of acid, in the process provided at temperature $25^{\circ} \mathrm{C}$ for 60 minutes. The results of the process optimization applying the fuzzy logic method and the function of the research object are consistent.

\section{ACKNOWLEDGEMENTS}

This work was performed as a part of the project No 1251/H03/2006/30.

\section{LITERATURE CITED}

1. Bolewski, A. (2004), Balance of Poland and World Minerals Economy 1998 - 2000. Polish Academy of Sciences: Mineral and Energy Economy Research Institute, Cracow, Poland. (in Polish).

2. Polish Geological Institute (2003), Map of zinc and lead ores deposits of Poland, from http://www.pgi.gov.pl/ surowce_mineralne/znpb.htm

3. Gruszczyk, H. \& Strzelecka-Smakowska, B. (1978). Minerals of World, Zinc - Zn, Lead - Pb, Cadmium - Cd, Warsaw, Poland: Wyd. Geol. (in Polish).

4. Sanak-Rydlewska, S. \& Małysa, E. (1996). Purification of zinc blende concentrate by chemical/flotation treatment of remove magnesium. Archives of Metallurgy 41(4), 435 - 440.

5. Małysa, E. \& Sanak-Rydlewska, S. (1999). Application of chemical methods in processing of zinc -lead ores. In New Trends in Mineral Processing (Part II), 24 - 26 June 1999 (pp. 367 - 373). Ostrava, Czech Republic: VSB-TU Ostrava.

6. Jarosiński, A. \& Fela, K. (2007), Application of sulphuric (VI) acid for magnesium removal from zinc concentrate. Pol. J. Chem. Tech. 9(2), 19-22. DOI: 10.2478/v10026-007-0017-8.

7. Jarosinski, A. \& Madejska, L. (2007), Magnesium removal from zinc concentrates by leaching. Pol. J. Environ. Stud. 16(3B), 196 - 199.

8. Fela, K., Jarosiński, A., Kozak A. \& Pietraszek A. (2007). Comparative study of magnesium removal from zinc concen- trate. Recyklace Odpadu XI, 6 - 7 December 2007 (pp. 71 76). Kosice, Slovakia: VSB-TU Ostrava.

9. Jarosiński, A. \& Fela, K. (2008). Acid leaching of zinc sulphide concentrate from Silesia-Cracow deposit of Poland. $12^{\text {th }}$ Conference on Environment and Mineral Processing: Proceedings (Part II), 5 - 7 June 2008 (pp. 49 - 54). Ostrava, Czech Republic: VSB-TU Ostrava.

10. Singh, V. (1996). Technological innovation in the zinc electrolyte purification process of a hydrometallurgical zinc plant through reduction in zinc dust consumption. Hydrometallurgy 40, 247 - 262.

11. Booster, J.L., van Sandwijk, A. \& Reuter M.A. (2000). Magnesium removal in the electrolytic zinc industry. Minerals Engineering 13(5), 517 - 526.

12. Górecka, R. (1998). Theory and technique of experiment (handbook). Cracow, Poland: Cracow University of Technology.

13. Zadeh, L. (1965). Fuzzy sets, Information and control. 8, $338-353$.

14. Mendel, J. (1995). Fuzzy logic systems for engineering: A tutorial. Proceedings of the IEEE 83(3), 345 - 377.

15. Bałaziński, M. (1997). Fuzzy logic, Biuletyn SIP 1, 1 - 5. (in Polish). 